\title{
Determining Optimum Tilt Angles of Photovoltaic Panels by Using Artificial Neural Networks in Turkey
}

\author{
Mustafa ŞAHIN
}

\begin{abstract}
Sun is the most important energy source of the world. To make use of this energy source effectively, the sun's angle of incidence to earth must be known. The angle, however, between rotation axis and orbital plane of the world is not constant and it changes continuously. Depending on this change, the incidence angle of sun beams also change. For purpose of increasing the light amount falling on solar panels, light beams must be adjusted according to their angles of incidence. The difference of this study from the studies in literature realized to determine the optimum tilt angle by means of mathematical methods is the determination of optimum tilt angles with artificial neural networks. In the study, not each province within boundaries of Turkey but the whole country as a system was introduced to the artificial neural network. Thanks to this, monthly optimum tilt angle of the system to be installed in any place within boundaries of Turkey was determined by the artificial neural network. The installed solar panels were adjusted according to this optimum tilt angle. Thanks to this, it was ensured to be obtained maximum output from solar panels. Mounting of the system according to an angle as predicted by artificial neural network has caused $34 \%$ increase in energy amount obtained from fixed solar panel systems. Consequently, in this study, in prediction of optimum tilt angle of fixed solar panels, in what extent the artificial neural networks are successful were observed. It was determined that correct results have been obtained in respect of both economy and utilization.
\end{abstract}

Keywords: Artificial Neural Networks; Optimum Tilt Angle; Renewable Energy; Solar Cell

\section{INTRODUCTION}

In recent years, concern on renewable energy and especially on solar energy has increased because of damages of fossil fuels on environment and depletion of such energy sources every passing day $[1,2]$. Sun is the most important energy source of the world. Sun energy, being an environmentally clean source, is an alternative to fossil fuels. Solar irradiation energy falling on earth every year is about 160 times of fossil fuel potential determined until today. Besides, it is 15.000 times more than the energy to be generated by fossil, nuclear and hydroelectric power plants on earth. The main problem here is to transform it to available energy form in conformity to human activities and make use of it most efficiently [3].

In generation of electric energy, combustion of fossil fuels like coal is mostly used. But, combustion of fossil fuels causes wastes like carbon dioxide, ash, etc. Such wastes have many negative effects on environment. Photovoltaic cells are one of the primary energy generation options that do not create environment polluting effect [4]. Turkey, locating in the north hemisphere, is a country having a very good sunshine duration, in respect to her mathematical location on world. According to recent studies, our country has $1100 \mathrm{kWh}$ solar energy potential per year $/ \mathrm{m}^{2}$. In this respect, solar energy is an important alternative energy source for our country $[5,6]$. The other factors that increase attractiveness of solar energy as an alternative energy source are high reliability of solar cells, their steady performances and fuel cost. In contrary to many advantages of solar energy use, it has disadvantages such as high installation costs and paying for itself in a long time.

Using of solar energy as an alternative energy to meet the increasing energy need of world must be extended. Besides, efficiency of solar cells must be increased. Today, a normal size solar cell can only be efficient for small powered commercial devices (calculators and toys). For devices requiring bigger electric power, bigger sized solar panels are needed. But, their big sizes create problems in practice. It is more logical to increase efficiency of each solar cell instead of increasing the size of panel [7]. Efficiency of solar cell depends on efficiency of cell and irradiation intensity on cell.

The difference of this study from the studies realized with mathematical methods is using of artificial neural networks in determination of optimum tilt angles. In the study, 7 cities of which optimum tilt angles previously measured were used. With data of these 7 cities, the artificial neural network was trained for forecasting of optimum tilt angle. Then, data for Eskişehir city were used to test ANN. In other words, optimum tilt angle of Eskişehir city that was not used in network training was estimated by ANN. It was observed that the values predicted by artificial neural network and values obtained as a result of long measurements were the same.

\subsection{Criteria Used in Determination of Tilt Angle of Solar Panels}

Materials used in generation of solar cells are one of the primary factors that limit efficiency of cell. This makes increasing of efficiency difficult and for this reason; it limits the whole performance of cell. On the other hand, increasing the irradiation amount falling on cell is an easier method. Especially, energy generation capacity of solar panels yearly decreases with stable positioning of them. [89]. In Fig. 1 below, a solar panel of which tilt angle has been changed manually is seen. Thanks to adjustable foot connected to the solar panel, angle of this solar panel can be changed in any desired value.

In this study, the purpose is to increase energy generation capacities of solar panels. Accordingly, it is aimed to maximize energy amount to be obtained by adjusting solar panel angles in definite intervals yearly. To obtain maximum efficiency yearly from solar panels to be installed in a region located in the north hemisphere, optimum tilt angle $\beta_{\text {opt }}$ of panel is equal to latitude $(\Phi)$ of that place. To obtain maximum efficiency in winter season, optimum tilt angle is $\beta_{\mathrm{opt}}=\Phi-15$ and to obtain maximum efficiency in summer season, optimum tilt angle is $\beta_{\text {opt }}=\Phi$ $+15[10,11]$. 

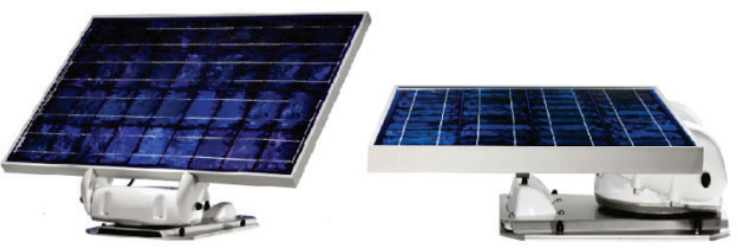

Figure 1 Solar panel with adjustable tilt angle

Here, the reason of numeric values added in latitude in determination of optimum tilt angle $\left(\beta_{\mathrm{opt}}\right)$ is the Zenit angle. This angle increases in winter months and decreases in summer months for the north hemisphere. The most important factor to be paid attention to in installation of solar panels is using purpose of the system. For instance, if the system will be installed for a seasonal work to be operated in maximum efficiency in any month yearly, tilt angle must be calculated according to that month. In the event that the system deviates $\pm 15^{\circ}$ from its ideal position in installation phase, energy losses occur. Solar panels are installed in a manner they will have tilt angles that change depending on geographical location of region they are used in. Monthly, seasonal and annual optimum values of this tilt angle for different cities were calculated. As there is a great difference between summer and winter values, it will be advantageous to use tilt angle values that change depending on months instead of annual or seasonal average values. By adjusting these, tilt angles manually within every month, more efficient operation of solar panel will be ensured [12-13-24]. Below, a current graphic generated by a mono crystalline solar cell at $21^{\circ} \mathrm{C}$ temperature, under 2000 lumen light intensity, maximum 3.6 volt output power and maximum $60 \mathrm{~A}$ current consumption in various light incidence angles is given (Fig. 2).

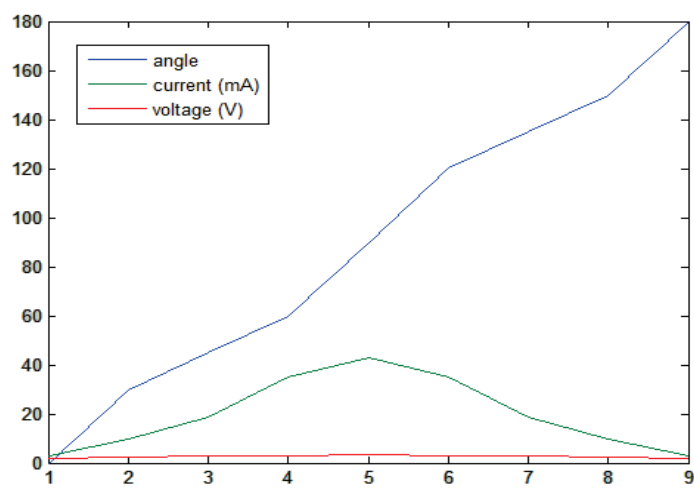

Figure 2 Current voltage graphic of a mono crystalline solar cell depending on a light incidence angle

As it can be understood from this graphic, in moment the incidence angle of solar beams is right (900), the current value generated by mono crystalline solar cell is maximum.

With summer month or winter month maximum efficiency indexed formulas referred to in ref. [10, 11], it is not possible to calculate the optimum tilt angle in any place and in any month clearly. However, with more complex mathematical calculations, optimum tilt angle can be calculated. There exist many international mathematical studies realized related to determination of optimum tilt angle [15-16-17]. Some of these studies are made in regions located within boundaries of Turkey [18] or nearby regions [19].

\subsection{Overview of Artificial Neural Networks}

ANN is an algorithm that learns, decides and extracts results like our brain processes. At the same time, they can reach the result by using the obtained data in case of insufficient data. The neurons in the ANN are complex systems that are interconnected by different connection geometries, as in biological neurons. These systems try to solve the problems which cannot be solved in a classical way by taking the working system of brain. A simple artificial neuron is a computation element with one or more scalar inputs and an output. Fig. 3 shows a neuron model with multiple inputs.

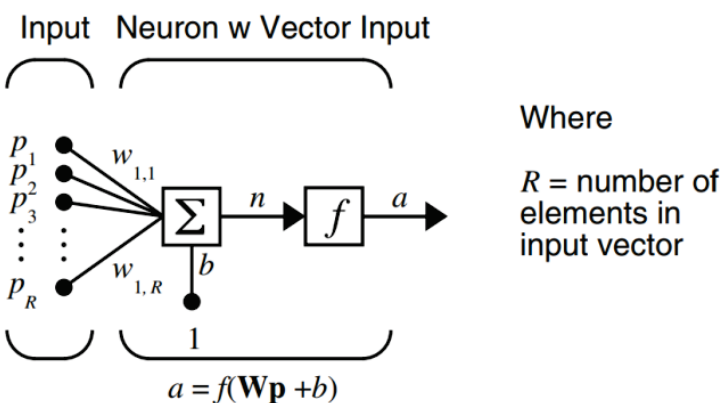

Figure 3 General principle schema of an ANN

The transfer function can be linear or non-linear differentiable function. The mathematical expression of the above model is as in Eq. (1).

$a=f \sum_{i=1}^{R} w_{i} P_{i}+b$

where: $P$ - scalar value of the input neuron; $w$ - the value of the weight between the $P$ and the neuron; $b$ - the bias value of the neuron; $f$ - transfer function; $a$ - the output of the neuron; $R$ - the number of elements in input vector.

In this study, a multi-layer feedback ANN model has been used. The block diagram of the feedback multi-layer perceptron (multi-layer perceptron - MLP) is given in Fig. $4[20,21]$.

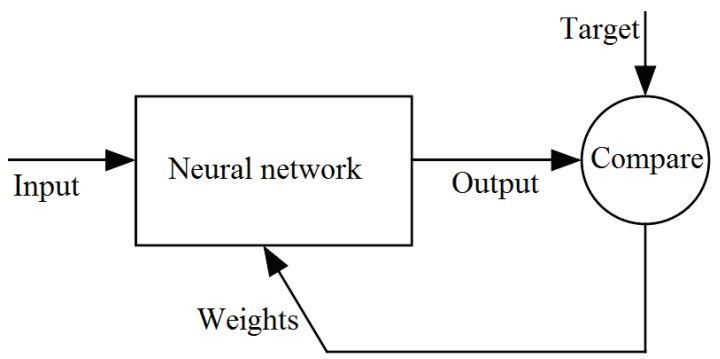

Figure 4 Block diagram for feedback network

ANN is widely used for the solution of non-linear problems. If ANN is not used, analytical computer codes and algorithms are required. Therefore, high-performance computers and sufficient time are needed to obtain and run these algorithms. By using ANN, you can obtain the important information needed from the existing database 
[22]. In addition, the ANNs are also able to process noisy and missing data and that means they have a high fault tolerance.

Studies related to ANN started at the beginning of the 20th century and quickly developed and reached its present position [23]. In recent years, it has been successfully used in many areas such as electrical, electronics, chemistry, production, robotics, material science [24-26], economics [27], physical metallurgy, automotive, defence and telecommunications [28].

\subsection{Solar Energy Potential and Irradiation Values of Turkey}

It was determined that annual average sunshine duration of Turkey, having high solar energy potential because of its geographical location, is 2.640 hours (daily total 7.2 hours) and average total irradiation intensity is $1.311 \mathrm{kWh} / \mathrm{m}^{2}$-year (daily total $3.6 \mathrm{kWh} / \mathrm{m}^{2}$ ). Solar energy potential of Turkey is 380 milliards $\mathrm{kWh} / \mathrm{year}$. It was calculated that Turkey could generate 380 milliards $\mathrm{kWh} /$ year energy with Solar Energy Potential Atlas and
CSP technology. In our country, the amount of installed solar collector is about 12 million $\mathrm{m}^{2}$, technical solar energy potential is 76 TEP (ton equal value petroleum) and annual generation volume is $750.000 \mathrm{~m}^{2}$ and some amount of this generation is exported. This amount of use means that $0.15 \mathrm{~m}^{2}$ of solar collector is being used per person. Annual generation of heat energy from solar energy is about 420.000 TEP. In recent situation, our country is a considerable solar collector generator and user in the world. Total installed powers of solar cells used for researches and to meet energy needs of small powered plants in Turkey have reached 1 MW [29]. The mean values of general irradiation in Turkey were calculated according to the information got from the Meteorology General Directorate and maps were established. Besides, "solar energy potential atlas" was established by the Electrical Power Resources Survey and Development Administration of Turkey. The solar energy potential atlas of Turkey is given in Fig. 5. [30].

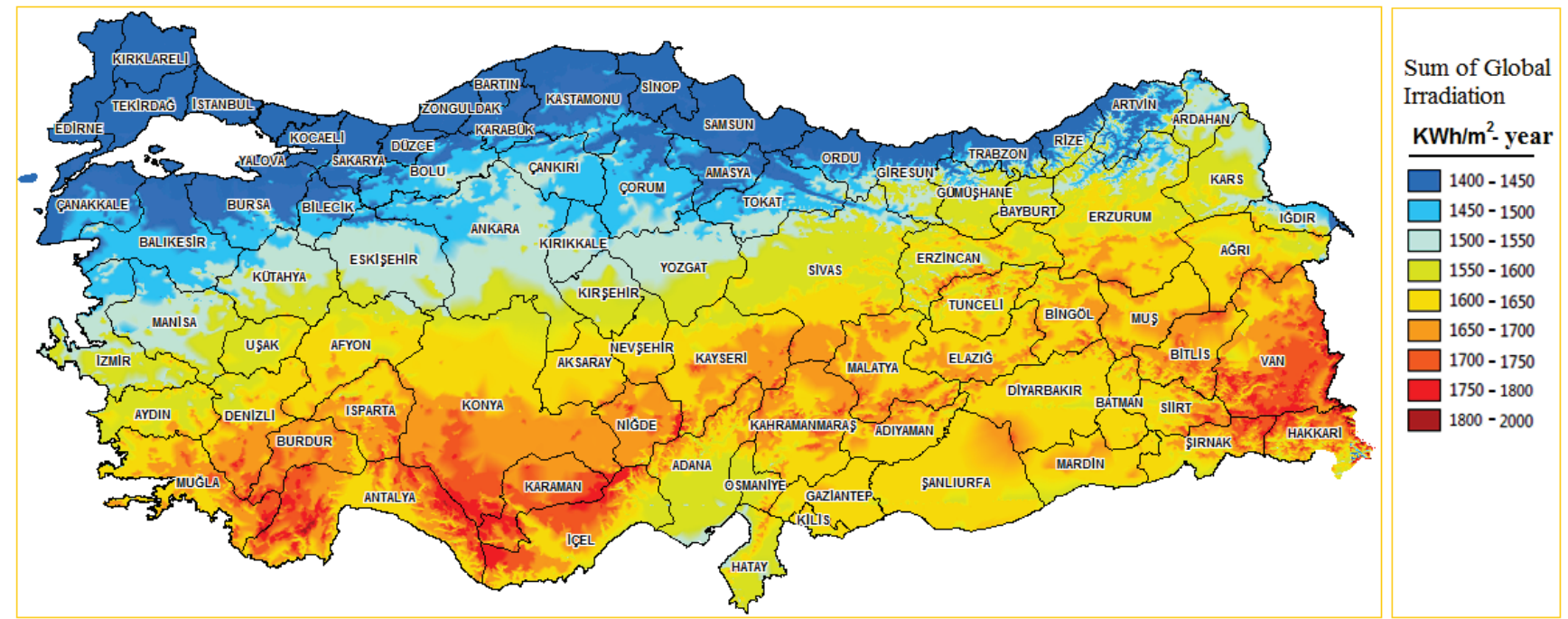

Figure 5 Global irradiation and solar electricity potential of Turkey (kWh/m² - year) [31].

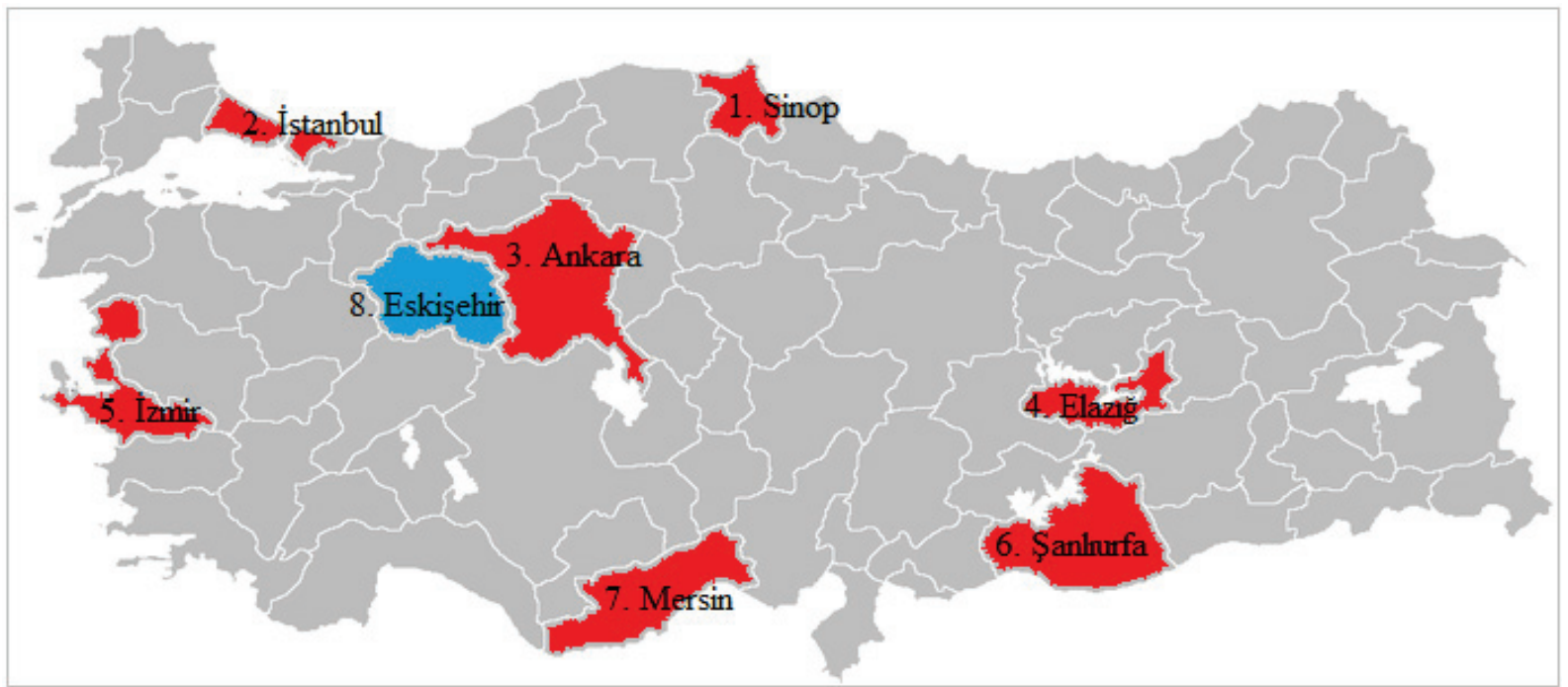

Figure 6 Locations of 7 cities used in ANN training (red points) and cities to be used for testing of ANN model (blue points) in geography of Turkey

Cerographical location and coordinates of a place effect incidence angle of solar beams. Besides, seasons and months of lived by that place also have an effect on incidence angle of solar beams. Additionally, sunshine durations and day lengths determine which period the place is in. In training of ANN model established according to 
these data, data of previously determined 7 cities were used. These previously determined 7 cities are stated with red points and numbered from 1 to 7 in Fig. 6 below.

Longitude and altitude coordinates of Turkey and 7 cities were used as input data in ANN training. In the study, the reason for using of longitude and altitude coordinates of Turkey, besides longitude and altitude data of cities, is to determine limits of study. In other words, the purpose is to introduce the country to ANN as a system and have monthly optimum tilt angle that belongs to any place within boundaries of Turkey made predictable by artificial neural network to be trained.

Additionally, months numbered from 1 to 12 and average sunshine durations (hour) by months of 7 cities in Turkey were used as input date in ANN training. To prove the relation between monthly sunshine durations of Turkey and 7 cities and optimum tilt angle, multi-variable regression analysis was made by means of PASW Statistics 18 program and colleration coefficient was found as 0.953 .

Monthly optimum tilt angles for 7 cities shown with red colour in Fig. 6 were used as target value of established ANN Data for 8 No Eskișehir shown with blue colour in
Fig. 6 were not used in network training. Optimum tilt angle of Eskişehir province represented with blue point was determined before with conventional methods and as a result of measurements lasted for months [33]. For testing the success of established artificial neural network in tilt angle prediction, optimum tilt angle of Eskişehir was predicted by ANN at the end of the study.

\section{ANN APPLICATION FOR SOLAR ANGLE PREDICTION}

Various mathematical methods have been used for utilization of fixed solar panels in the most efficient manner throughout the year. [31, 32]. In this study, for prediction of optimum tilt angle values that belong to fixed solar panel to be installed in any place within boundaries of Turkey, a feed forward artificial neural network model was used. For making any prediction with artificial neural networks, first of all, the network to be established must be trained. Variables used in training of artificial neural network are input and output values. In this study, multilayer artificial neural network was used (Fig. 7).

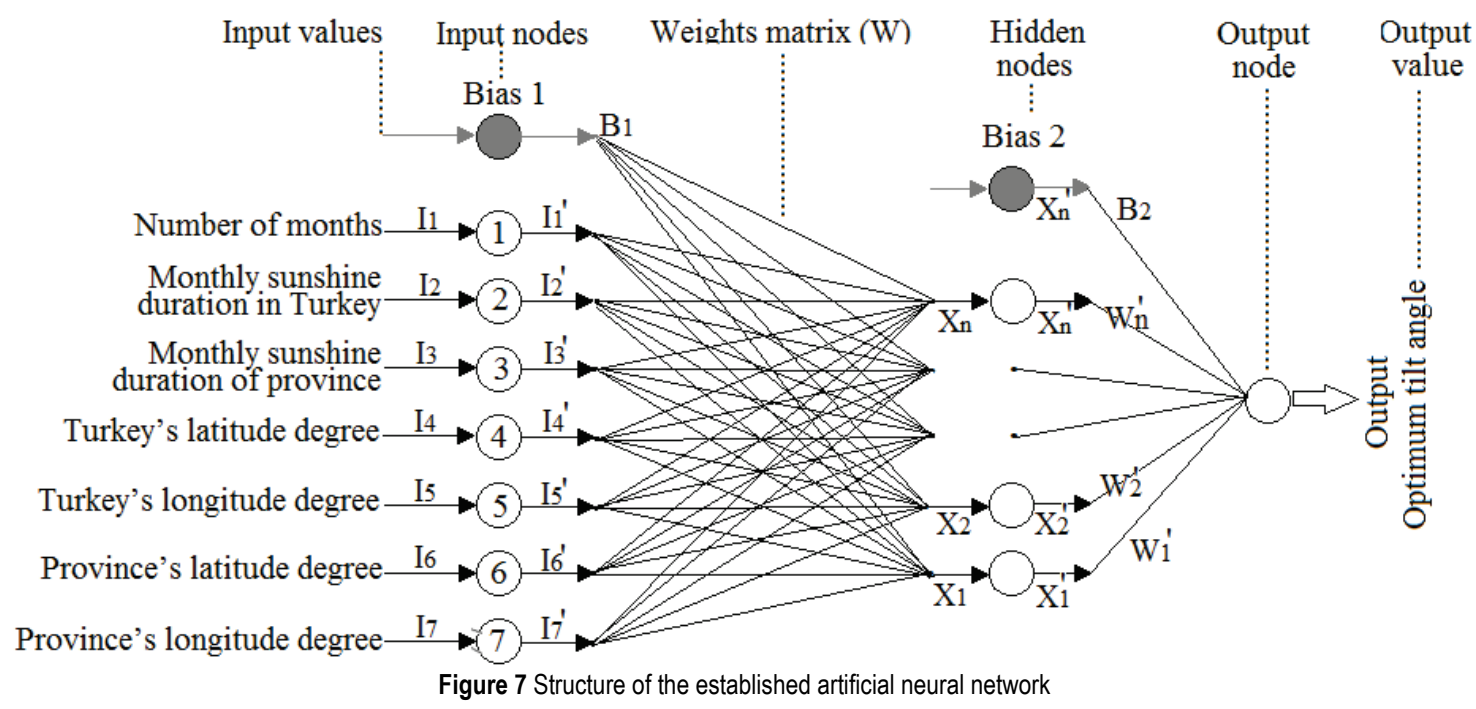

Table 1 The number of input and output values of the network

\begin{tabular}{|c|l|r|}
\hline Code & \multicolumn{1}{|c|}{ Input Variable } & Total \\
\hline$X_{1}$ & Number of months & 12 \\
\hline$X_{2}$ & Monthly sunshine duration in Turkey & 12 \\
\hline$X_{3}$ & Monthly sunshine duration of provinces & 84 \\
\hline$X_{4}$ & Turkey's latitude degree & 2 \\
\hline$X_{5}$ & Turkey's longitude degree & 2 \\
\hline$X_{6}$ & Provinces's latitude degrees & 7 \\
\hline$X_{7}$ & Provinces's 1 longitude degrees & 7 \\
\hline Code & Output Variable & Total \\
\hline$Y_{1}$ & Optimum tilt angle & 84 \\
\hline
\end{tabular}

Table 2 The input and output variables used in the model construction.

\begin{tabular}{|c|l|c|c|}
\hline \multirow{2}{*}{ Code } & \multicolumn{1}{|c|}{ Input Variable } & \multicolumn{2}{c|}{ Data used in ANN mode } \\
\cline { 3 - 4 } & & 12 & Maximum \\
\hline$X_{1}$ & Number of months & 11,31 & 3,75 \\
\hline$X_{2}$ & Monthly sunshine durationin Turkey & 12,42 & 2,96 \\
\hline$X_{3}$ & $\begin{array}{l}\text { Monthly sunshine duration of } \\
\text { provinces }\end{array}$ & 42 & 36 \\
\hline$X_{4}$ & Turkey's latitude degree & 45 & 26 \\
\hline$X_{5}$ & Turkey's longitu dedegree & 42 & 36,48 \\
\hline$X_{6}$ & Provinces's latitude degrees & 39,14 & 27,09 \\
\hline$X_{7}$ & Provinces's l longitude degrees & 65,1 & 13,4 \\
\hline$Y_{1}$ & Optimum tilt angle & \multicolumn{2}{c}{} \\
\hline
\end{tabular}

As it is seen in Fig. 7, input variables of established network consist of 7 components and output values consist of 1 component. The input and output variables of network and their values in number are given inTab. 1.

As it is seen in Tab. 1, for training of the established artificial neural network, 126 input variables and 84 output variables - total 210 variables - were used. Maximum and minimum values of 7 input groups and 1 output group used in network training are given in Tab. 2.

Weight and target data are subjected to some preprocess before the ANN training. This pre-process is defined as normalization and the aim of this pre-process is to improve the performance of ANN. In this way, ANN can work with more efficiency. Since raw weight and target values cannot be used directly in ANN training, the normalization process must be applied to these raw data. The data used for ANN training pass through threshold functions in their transition between layers. The change interval of the outputs of these functions is $[-1,1]$ or $[0,1]$. Therefore, raw data should be taken to these intervals in order to be used in education. In other words, the 
information region is in the range of 0 and 1 in most applications.

In this study, Max-Min method is used as normalization method. Here, maximum represents the highest value and minimum represents the lowest value of data. The following equation is used for normalization.

$$
x^{\prime}=\frac{x_{i}-x_{\min }}{x_{\max }-x_{\min }}
$$

where: $x^{\prime}$ - normalized data; $x_{i}$ - input values; $x_{\max }$ - highest input value; $x_{\min }$ - lowest input value.

In training of ANN, normalized data has been used (Tab. 3). After estimation, the actual values were obtained by inverse transformation. In this study, LevenbergMarquardt (LM) algorithm was used as the training algorithm for ANN education. This algorithm was preferred because it accelerated and improved the training of ANN.

Table 3 The normalized input variables used in the model construction

\begin{tabular}{|c|l|l|l|}
\hline \multirow{2}{*}{ Code } & \multicolumn{1}{|c}{ Input Variable } & \multicolumn{1}{c|}{ Data used in ANN model } \\
\cline { 3 - 4 } & & 0,25 & 0 \\
\hline$X_{1}$ & Number of months & 0,234318 & 0,0625 \\
\hline$X_{2}$ & $\begin{array}{l}\text { Monthly sunshine duration in } \\
\text { Turkey }\end{array}$ & 0,259545 & 0,044545 \\
\hline$X_{3}$ & $\begin{array}{l}\text { Monthly sunshine duration of } \\
\text { provinces }\end{array}$ & 0,931818 & 0,795455 \\
\hline$X_{4}$ & Turkey'slatitude degree & 1 & 0,568182 \\
\hline$X_{5}$ & Turkey's longitude degree & 0,931818 & 0,806364 \\
\hline$X_{6}$ & Provinces's latitude degrees & 0,866818 & 0,592955 \\
\hline$X_{7}$ & Provinces's 1 longitude degrees & 0,25 & 0 \\
\hline$Y_{1}$ & Optimum tilt angle & & \\
\hline
\end{tabular}

\section{COMPARISON OF ANN METHOD WITH OTHER METHODS IN PREDICTION OF TILT ANGLE}

It is not possible to calculate optimum tilt angle in any place and in any month clearly according to formulas [10, 11] suggested in conventional calculating methods. However, with more complex mathematical calculations, optimum tilt angle can be calculated [15-16-17] or by setting up some mechanisms and supporting such mechanisms with various computer programs, and with daily measurements for each month in every city, it is possible to determine monthly average optimum tilt angle [33]. However, this is an expensive, tiring and time consuming process.

Mehleri has used two modelling methods to calculate optimum tilt angle. These are standard multiple linear regression (MLR) and the radial-basis function neural network architecture [34]. Chang has made a study to obtain maximum output power in PV modules. In Mehleri's study, sequential neural-network approximation and orthogonal arrays (SNAOA) were used to determine the optimum tilt angle [35]. Notton developed three ANN models in order to determine the optimum tilt angle and estimated the hourly global radiation on the tilted plane with these models [36]. Celik used generalized regression neural networks (GRNN) to estimate solar radiation on the tilted plane [37]. Chatterjee used ANN model which has 14 inputs to predict optimum tilt and total irradiance in PV modules [38]. In Yadav's study, optimum solar panel tilt angle methods using different optimization techniques are reviewed [16]. In this study, feed-forward ANN model that is different from other works was developed to estimate the optimum tilt angle. Input-output variables, the number, and quality of these variables are different from other studies. Moreover, the ANN model used in the study has different topology according to the ANN models in the literature.

In this study, in prediction of optimum tilt angle, ANN was used instead of tiring and time consuming processes.

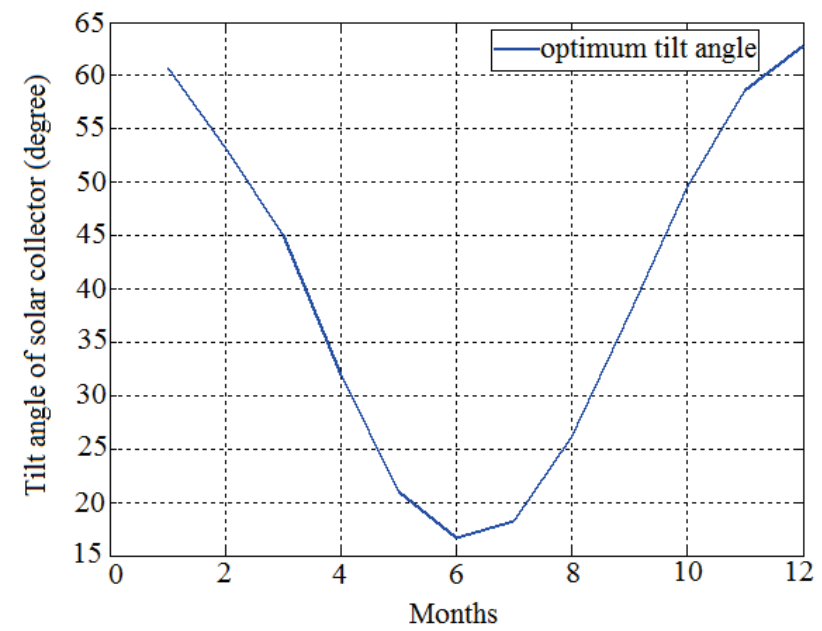

Figure 8 Annual optimum tilt angle graphic for Eskişehir city

For this purpose, optimum tilt angles of 7 cities were determined previously and so established artificial neural network was trained. Eskişehir represented with blue point in Figure 6 was used for test purpose and data of that city were not used in ANN training. Optimum tilt angle of Eskişehir was determined as 400 as a result of measurements realized with conventional methods that lasted 1 year. [33]. Then, optimum tilt angle value of Eskişehir was determined with artificial neural network prediction and found as 40.130. Besides, annual optimum tilt angle graphic for Eskişehir city was obtained by established artificial neural network as seen in Fig. 8 below.

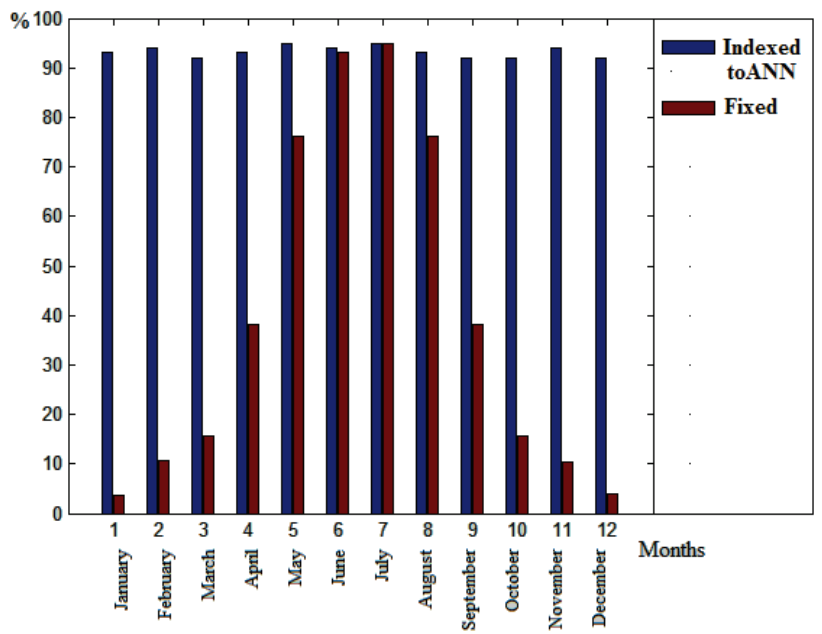

Figure 9 Annual power distribution percentages of monthly adjusted (blue bands) and constant angle (red bands) panels according to angles predicted by ANN

In the study, a 12-month energy percentage graphic obtained from solar panel adjusted according to monthly average optimum tilt angles as predicted by artificial neural 
network was prepared. These percentages are shown in blue bands in Fig. 9. Besides, a 12-month energy percentage graphic obtained from solar panel as adapted according to maximum efficiency in summer season was prepared. These percentages are shown in red bands in Fig. 9. At the end of the study, the system installed summerfocus and the system adjusted manually every month according to ANN prediction were compared. As a result of the comparison, it was observed that the solar panel systems adjusted every month are $34 \%$ more efficient than the solar panel systems adjusted according to a fixed angle yearly, according to values predicted by artificial neural networks.

When mounting of $1 \mathrm{~kW}$ PV (Photovoltaic) system was made according to conventional calculating methods in adapted manner [10, 11], annual total $2190(\mathrm{~kW} /$ year $)$ electric energy was obtained. However, when optimum tilt angle was predicted by artificial neural network for each month and solar panel was adjusted according to this angle value monthly, it was observed the obtained electric energy value reached the value of $2950 \mathrm{~kW} /$ year.

\section{CONCLUSION}

In this study, importance of solar energy systems and advantages of using of artificial neural networks in determination of optimum tilt angle of fixed solar panels during and after mounting of panels are discussed. Accordingly, an artificial neural network for prediction of optimum tilt angle was established. By using this established artificial neural network, the predicted optimum tilt angle values and actual angle values were compared. In designing phase of solar energy systems, various computer programs and mathematical calculating methods were used in determination of optimum tilt angle and it was observed that artificial neural networks provided feedback quickly and in a short time. Consequently, it was proved that artificial neural networks are rather successful in determination of optimum tilt angles of fixed solar panels. It was proved that the solar panels adjusted according to value predicted by ANN are 34\% more efficient than the solar panels installed according to conventional calculating methods.

\section{REFERENCES}

[1] Bica, D. \& Cristian, D. (2008, September). Photovoltaic laboratory for study of renewable solar energy. $43^{\text {rd }}$ International IEEE Universities Power Engineering Conference, UPEC 2008, 1-5. https://doi.org/10.1109/UPEC.2008.4651577

[2] Benedek, J., Sebestyén, T. T., \& Bartók, B. (2018). Evaluation of renewable energy sources in peripheral areas and renewable energy-based rural development. Renewable and Sustainable Energy Reviews, 90, 516-535. https://doi.org/10.1016/j.rser.2018.03.020

[3] Varınca, K. B. \& Gönüllü, M. T. (2006). Solar Power Potential İn Turkey. The First Solar Power and Hydrogen Power Symposium, Turkey.

[4] Batman, M. A. (2001). A New Method to Increase the Operational Efficiency of Solar Cells for Generating Electricity. İstanbul Technical University, Doctorate thesis, Turkey.

[5] Altın, V. (2004). Production of Electrical Energy from Solar Power. Journal of Science and Architecture, 33, 28-31.
[6] İscan, S., Karayel, R., Özcan Z. O., \& Gürleyen, Ş. (2012). Solar Tracking System (2-Way). MKT2012, Project-Based Mechatronics Symposium, Turkey.

[7] Abdallah, S. \& Badran, O. O. (2008). Sun tracking system for productivity enhancement of solar still. Desalination, 220(1-3), 669-676. https://doi.org/10.1016/j.desal.2007.02.047

[8] Acar, C. \& Kılınçdemir, İ. (2010). Cost Analysis of Solar Tracking Systems. Yıldız Technical University, Project in Electrical and Electronic Engineering Department, İstanbul.

[9] Duffie, J. A. \& Beckman, W. A. (2013). Solar engineering of thermal processes. John Wiley \& Sons. https://doi.org/10.1002/9781118671603

[10] Gunerhan, H. \& Hepbasli, A. (2007). Determination of the optimum tilt angle of solar collectors for building applications. Building and Environment, 42(2), 779-783. https://doi.org/10.1016/j.buildenv.2005.09.012

[11] Beringer, S., Schilke, H., Lohse, I., \& Seckmeyer, G. (2011). Case study showing that the tilt angle of photovoltaic plants is nearly irrelevant. Solar energy, 85(3), 470-476. https://doi.org/10.1016/j.solener.2010.12.014

[12] Garg, H. P. (2000). Solar energy: fundamentals and applications. Tata McGraw-Hill Education.

[13] Özturk, H. (2008). Sun Power and Applications, Birsen Publishing, Updated Edition, İstanbul.

[14] Messenger, R. A. \& Abtahi, A. (2017). Photovoltaic systems engineering. CRC press. https://doi.org/10.1201/9781315218397

[15] Darhmaoui, H. \& Lahjouji, D. (2013). Latitude based model for tilt angle optimization for solar collectors in the Mediterranean region. Energy Procedia, 42, 426-435. https://doi.org/10.1016/j.egypro.2013.11.043

[16] Yadav, A. K. \& Chandel, S. S. (2013). Tilt angle optimization to maximize incident solar radiation: A review. Renewable and Sustainable Energy Reviews, 23, 503-513. https://doi.org/10.1016/j.rser.2013.02.027

[17] Jafarkazemi, F. \& Saadabadi, S. A. (2013). Optimum tilt angle and orientation of solar surfaces in Abu Dhabi, UAE. Renewable energy, 56, 44-49. https://doi.org/10.1016/j.renene.2012.10.036

[18] Kacira, M., Simsek, M., Babur, Y., \& Demirkol, S. (2004). Determining optimum tilt angles and orientations of photovoltaic panels in Sanliurfa, Turkey. Renewable energy, 29(8), 1265-1275. https://doi.org/10.1016/j.renene.2003.12.014

[19] Skeiker, K. (2009). Optimum tilt angle and orientation for solar collectors in Syria. Energy Conversion and Management, 50(9), 2439-2448. https://doi.org/10.1016/j.enconman.2009.05.031

[20] Şahin, M., Oğuz, Y., \& Büyüktümtürk, F. (2016). ANNbased estimation of time-dependent energy loss in lighting systems. Energy and Buildings, 116, 455-467. https://doi.org/10.1016/j.enbuild.2016.01.027

[21] Şahin, M., Oğuz, Y., \& Büyüktümtürk, F. (2015). Approximate and Three-Dimensional Modeling of Brightness Levels in Interior Spaces by Using Artificial Neural Networks. Journal of Electrical Engineering and Technology, 10(4), 1822-1829. https://doi.org/10.5370/JEET.2015.10.4.1822

[22] Zupan, J. (2018). 11.2 Artificial Neural Networks (ANNs). Chemoinformatics: Basic Concepts and Methods, 438. https://doi.org/10.1002/9783527816880.ch11_02

[23] Medsker, L. R. (1997). The future of artificial neural networks could be bright. Vivek-Bombay, 10, 28-29.

[24] Jančíková, Z., Zimný, O., \& Koštial, P. (2013). Prediction of metal corrosion by neural networks. Metalurgija, 52(3), 379-381.

[25] Can, E. \& Sayan, H. H. (2016). PID and fuzzy controlling three phase asynchronous machine by low level DC source three phase inverter. Tehnički vjesnik, 23(3), 753-760. https://doi.org/10.17559/TV-20150106105608 
[26] Marouf, A. \& Abu-Naser, S. S. (2018). Predicting Antibiotic Susceptibility Using Artificial Neural Network. International Journal of Academic Pedagogical Research (IJAPR), 2(10), $1-5$.

[27] Pang, X., Zhou, Y., Wang, P., Lin, W., \& Chang, V. (2018). An innovative neural network approach for stock market prediction. The Journal of Supercomputing, 1-21. https://doi.org/10.1007/s11227-017-2228-y

[28] Glowacz, A. (2018). Acoustic based fault diagnosis of threephase induction motor. Applied Acoustics, 137, 82-89. https://doi.org/10.1016/j.apacoust.2018.03.010

[29] Republic of Turkey, (2017 January 12). Ministry of Energy and Natural Resources, http://www.enerji.gov.tr.

[30] Republic of Turkey, (2017 February 9). Ministry of Energy and Natural Resources, General Directorate of Renewable Energy, http://www.yegm.gov.tr (11.10. 2017)

[31] Ghosh, H. R., Bhowmik, N. C., \& Hussain, M. (2010). Determining seasonal optimum tilt angles, solar radiations on variously oriented, single and double axis tracking surfaces at Dhaka. Renewable Energy, 35(6), 1292-1297. https://doi.org/10.1016/j.renene.2009.11.041

[32] Tang, R. \& Wu, T. (2004). Optimal tilt-angles for solar collectors used in China. Applied energy, 79(3), 239-248. https://doi.org/10.1016/j.apenergy.2004.01.003

[33] Şadanoğlu, İ. (2008). Determining of the Optimum Tilt Angles in Eskisehir in Turkey, Master's Degree Thesis, Eskisehir, Turkey.

[34] Mehleri, E. D., Zervas, P. L., Sarimveis, H., Palyvos, J. A., \& Markatos, N. C. (2010). Determination of the optimal tilt angle and orientation for solar photovoltaic arrays. Renewable Energy, 35(11), 2468-2475. https://doi.org/10.1016/.renene.2010.03.006

[35] Chang, Y. P. (2009). Optimal design of discrete-value tilt angle of PV using sequential neural-network approximation and orthogonal array. Expert Systems with Applications, 36(3), 6010-6018. https://doi.org/10.1016/j.eswa.2008.06.105

[36] Notton, G., Paoli, C., Vasileva, S., Nivet, M. L., Canaletti, J. L., \& Cristofari, C. (2012). Estimation of hourly global solar irradiation on tilted planes from horizontal one using artificial neural networks. Energy, 39(1), 166-179. https://doi.org/10.1016/j.energy.2012.01.038

[37] Celik, A. N. \& Muneer, T. (2013). Neural network based method for conversion of solar radiation data. Energy conversion and management, 67, 117-124. https://doi.org/10.1016/j.enconman.2012.11.010

[38] Chatterjee, A. \& Keyhani, A. (2012). Neural network estimation of microgrid maximum solar power. IEEE Transactions on Smart Grid, 3(4), 1860-1866. https://doi.org/10.1109/TSG.2012.2198674

\section{Contact information:}

Mustafa SAHIN, Asst. Prof. Dr.

Afyon Kocatepe University,

Technology Faculty, Electrical and Electronic Engineering,

Gazlıgöl, 03200, Afyonkarahisar, Turkey

E-mail: mustafasahin@aku.edu.tr 